\title{
Growth and subculture of pathogenic T. pallidum (Nichols strain) in BHK-21 cultured tissue cells
}

\author{
R. H. JONES, M. A. FINN, J. J. THOMAS, AND C. FOLGER \\ Medical Research Institute, Florida Institute of Technology, Melbourne, Florida, U.S.A.
}

\section{Summary}

The growth and nine subcultivations of the experimental Nichols strain of pathogenic Treponema pallidum were successfully accomplished in cultured baby hamster kidney tissue cells (BHK-21) using serum-free media. The number (motile and nonmotile cells occurring extracellularly) of cell generations generally increased with each subcultivation, the largest increases $(>3.0)$ occurring in subcultures $4,5,7,8$, and 9 . Also, the number of motile cells decreased with each subcultivation. Virulent organisms were demonstrated in subcultures $1,4,5,7$, and 8 , and their numbers estimated with the use of standards established by the animal inoculation titration of counted numbers of organisms freshly harvested from experimental infections; the estimated number of virulent organisms was higher than or equal to the counted cultivated treponemes injected, which may be attributable to uncounted virulent spirochaetes occurring intracellularly.

\section{Introduction}

The first recorded attempt to cultivate pathogenic treponemata in vitro consisted of deeply embedding a small piece of human syphilitic tissue into autolysed gelatinized horse serum (Schereschewsky, 1909a, b, c). Apparently, this procedure proved unsuccessful in cultivating virulent Treponema pallidum, although the investigator claimed to have purified the organism with which he subsequently infected rabbits and mice (Schereschewsky, 1912, 1955). Noguchi $(1911,1912)$ reported the growth in vitro of virulent T. pallidum in pure culture. Levaditi and Danulesco (1912) studied cultures received from Noguchi and concluded that they were avirulent non-pathogenic contaminants. Subsequent attempts at cultivating pathogenic treponemes in vitro, using ordinary bacteriological media, tissue culture, or egg culture methods have been unsuccessful (Turner and Hollander, 1957; Willcox and Guthe, 1966; Fitzgerald, Miller, and Sykes, 1975). In this paper we describe the successful cultivation and subculturing of the experimental Nichols strain of virulent $T$. pallidum using a tissue culture system.

\section{Material and methods}

\section{TEST ANIMALS}

New Zealand white rabbits were bred and raised indoors at $20^{\circ} \mathrm{C}$. in the Medical Research Institute (MRI) colony and fed Purina Rabbit Chow and water ad lib. Rabbits in the MRI colony have never shown any physical evidence of infection with Treponema cuniculi or Rapid Plasma Reagin (RPR) antibodies (Small and Newman, 1972).

\section{ORGANISMS}

The virulent $T$. pallidum (Nichols strain) was acquired from infected rabbits sent from the Center for Disease Control, Atlanta, Georgia, April, 1972, and since passed intratesticularly in rabbits. Treponemes used in this study came from rabbits infected with $T$. pallidum showing a well-developed orchitis. The testes were aseptically removed, minced, and dipped in phosphate buffered saline (PBS) (pH 7.4) to remove loose cellular debris and extracellular tissue fluids. The testicular material was then swirled in fresh tissue culture medium-1 (TCM-1) (see Table I) for 30 to $60 \mathrm{~min}$. and the number of cells determined by the method of Chandler and Cannefax (1969). This method of counting was used throughout the study.

\section{TISSUE CULTURE}

Baby hamster kidney cells (BHK-21) (Macpherson and Stoker, 1962) were routinely cultured in Eagle's minimal essential medium (MEM) (Eagle, 1959) including Earle's balanced salt solution (EBSS) (Earle, 1943) and supplemented to contain 10 per cent. fetal calf serum (MEM10 per cent. FCS).

In establishing cell culture monolayers for use in treponemal studies, wells of multi-dish tissue culture plates (10 × 35 mm., Linbro Chemical Company, Inc.) were inoculated with $3 \mathrm{ml}$. of MEM-2 per cent. FCS containing 
$10^{5}$ tissue cells. These cells were taken from routine cultures, washed three times in EBSS lacking calcium and magnesium salt ions (GKNP) and re-suspended for use in MEM-2 per cent. FCS. Cell counts were determined with a haemocytometer under bright field microscopy. The cell cultures were incubated overnight at $33^{\circ} \mathrm{C}$. in an atmosphere of 7 per cent. $\mathrm{CO}_{2}$ in air. After incubation, the medium was decanted and the cell monolayers washed three times with GKNP. A $3 \mathrm{ml}$. volume of TCM-1 (see Table I) was added to each multi-dish well and the cultures re-incubated for $24 \mathrm{hrs}$. At this time the medium was decanted and the monolayers washed three times with GKNP, supplementing each monolayer with $3 \mathrm{ml}$. of fresh TCM-1. After an additional $24 \mathrm{hrs}$ ' incubation, the cell monolayers were observed as a +2 on a 1 to $4+$ monolayer growth confluency scale. The medium was then decanted, and the cell monolayers washed three times with GKNP and then supplemented with $3 \mathrm{ml}$. fresh TCM-1 containing $1.87 \times 10^{5}$ treponemes $/ \mathrm{ml}$. freshly harvested from infected rabbit testes. The inoculated cultures were incubated at $33^{\circ} \mathrm{C}$. in an atmosphere of 7 per cent. $\mathrm{CO}_{2}$ in air, and the numbers of treponemes were determined after $24 \mathrm{hrs}$.

TABLE I Tissue Culture Medium 1 (TCM-1) Recipe*

\begin{tabular}{|c|c|c|}
\hline Ingredients & $m l$. & Source \\
\hline $\begin{array}{l}\text { Earle's balanced salt solution }(10 \times) \\
\text { Eagle's MEM amino acids }(50 \times) \text { without }\end{array}$ & $100 \cdot 0$ & a \\
\hline glutamine & $20 \cdot 0$ & a \\
\hline Eagle's MEM vitamins $(100 \times)$ & $10 \cdot 0$ & a \\
\hline Glutamine $(200 \mathrm{mM})(100 \times)$ & $10 \cdot 0$ & a \\
\hline Vitamin $B_{12}(150 \mu \mathrm{g} . / \mathrm{ml}).(1,000 \times)$ & $1 \cdot 0$ & b \\
\hline Biotin $(100 \mu \mathrm{g} . / \mathrm{ml}).(1,000 \times)$ & $1 \cdot 0$ & b \\
\hline Cobalt chloride $(0.5 \mu \mathrm{g} / \mathrm{ml}).(100 \times)$ & $10 \cdot 0$ & c \\
\hline $\mathrm{NaHCO}_{3}$ (7 per cent.) & $17 \cdot 5$ & \\
\hline BSA-Na oleate complex & $40 \cdot 0$ & \\
\hline BSA-Na stearate complex & $65 \cdot 0$ & $c^{\star \star}$ \\
\hline Phenol red ( 0.5 per cent.) & $12 \cdot 5$ & c \\
\hline Mannitol (10 per cent.) & $100 \cdot 0$ & c \\
\hline Catalase $(32,000$ units $/ \mathrm{ml})$. & $10 \cdot 0$ & e \\
\hline Distilled water (Triple glass distilled) & $603 \cdot 0$ & \\
\hline Total & $1,000 \cdot 0$ & \\
\hline \multicolumn{3}{|c|}{$\begin{aligned} \mathrm{a}= & \text { International Scientific Industries (Cary, Ill.) } \\
\mathrm{b}= & \text { Sigma (St. Louis, Mo.) } \\
\mathrm{c}= & \text { Mallinckrodt (St. Louis, Mo.), c } \mathrm{c}^{\star \star}=\text { stearic acid } \\
\mathrm{d}= & \text { Bovine serum albumin, Pentex fr. V, lipid poor, } \\
& \text { Lot } 27 \text { (Miles Labs., South Bend, Ind.) } \\
\text { Oleic acid (Hormel Institute, Austin, Minn.) } & \text { Olid }=\text { Worthington (Freehold, N.J.) }\end{aligned}$} \\
\hline
\end{tabular}

The supernatant fluids were removed from the cell monolayers and the number of motile and non-motile treponemes determined. The cells from which the supernatant fluid had been removed were scraped from the surface of the plastic substratum with the aid of a rubber policeman, suspended in $3 \mathrm{ml}$. of fresh TCM-1, gently pipetted to disperse any cell clumps, and counts of freely occurring motile and non-motile treponemes determined.

For subculturing, the number of cultured treponemes was adjusted to approximately $2 \times 10^{5} \mathrm{ml}$. A $3 \mathrm{ml}$. volume of this cell suspension was added to each multidish well containing fresh cell cultures prepared as previously described.

TCM-1 without the added mannitol and catalase was analysed in a concurrent experiment (B). For simplicity, the modified TCM-1 is referred to as TCM-2.
The bovine serum albumin (BSA) sodium oleate complex (see Table I) was made by adding $0.075 \mathrm{ml}$. oleic acid $(67 \cdot 125 \mathrm{mg}$.) to $5 \mathrm{ml}$. $0 \cdot 1 \mathrm{~N} \mathrm{NaOH}$ under rapid agitation to which $17 \cdot 5 \mathrm{ml}$. GKNP (pH $7 \cdot 0-7 \cdot 2$ ) was added. A $1.65 \mathrm{ml}$. volume of this solution was added to $25 \mathrm{ml}$. of a 10 per cent. BSA solution (made in distilled water) and $23.35 \mathrm{ml}$. of GKNP for a total of $50 \mathrm{ml}$. from which $40 \mathrm{ml}$. was added to the final medium.

The BSA-sodium stearate complex was made by dissolving $5 \mathrm{mg}$. stearic acid in $25 \mathrm{ml} .0 \cdot 1 \mathrm{~N} \mathrm{NaOH}$ at $60^{\circ} \mathrm{C}$. under rapid agitation. This solution was cooled to below $50^{\circ} \mathrm{C}$. and added to $20 \mathrm{ml}$. of a 10 per cent. BSA solution and $20 \mathrm{ml}$. GKNP for a total volume of $65 \mathrm{ml}$. which was added to the final medium.

\section{VIRULENCE TITRATIONS}

A standard curve between the time of lesion development and the serial numbers of freshly harvested treponemes injected intradermally (ID) on each side of shaved backs of rabbits was determined from three different experiments (Figure). Each level of treponemes was injected into a total of six rabbits representing twelve sites of inoculation. Times of lesion development are charted as an arithmetic mean for each cell number injected.

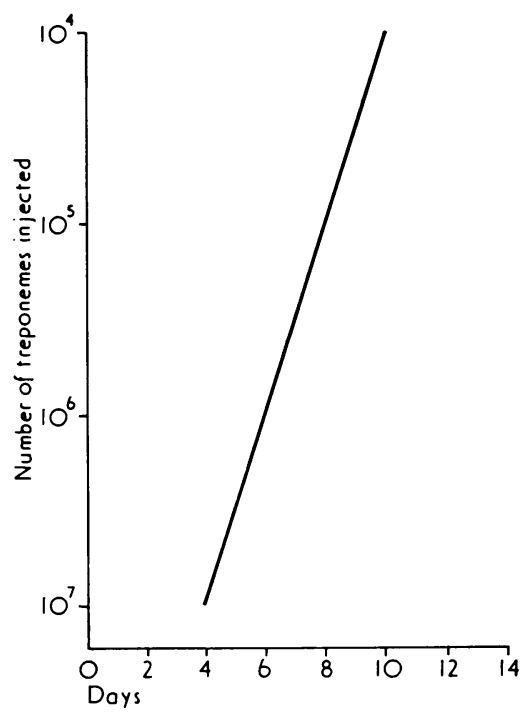

FIGURE Standard curve used for estimating numbers of cultivated virulent $\mathbf{T}$. pallidum cells in $0.1 \mathrm{ml}$. injected intradermally into rabbits. Curve was established using T. pallidum cells freshly harvested from experimental orchitic rabbit testes

From each subculture, supernatant fluid and cellassociated treponemes were combined and adjustments made with fresh TCM-1 or TCM-2 to provide $0.1 \mathrm{ml}$. volumes containing $10^{5}$ and $10^{3}$ (motile plus non-motile) treponemes, respectively. Each inoculum level was injected intradermally on each side of a shaved back of one or both of two female rabbits as indicated. The inoculated sites were monitored daily and time of lesion development 
recorded and compared to the standard curve for estimating number of virulent organisms injected. The presence of treponemes in developed lesions was confirmed by darkfield microscopy. As controls, uninfected tissue cells incubated for 24 hrs were harvested and cell numbers adjusted with TCM-1 or TCM-2 so as to be comparable to that of the infected cells injected into rabbits. Volumes of $0.1 \mathrm{ml}$. of the respective adjusted numbers of uninoculated cells were injected twice intradermally on the shaven backs of each of two female rabbits. All injected animals were maintained in an environmental temperature of $20^{\circ} \mathrm{C}$. or less.

\section{Results}

Table II shows the growth and subculture of $T$. pallidum spirochaetes on partial monolayers of $\mathrm{BHK}$ 21 cells in TCM-1 or TCM-2. The number of cell generations increased in the primary transfer and for each subculture, showing a steady increase throughout nine subcultures in both experiments.

For the TCM-1-BHK-21 culture system, the arithmetic mean number of cell generations is 2.97 (range 2.57 to 3.47 ), the largest $(>3.0)$ increases occurring in subcultures $4,5,8$, and 9.

For the TCM-2-BHK-21 culture system, the arithmetic mean number of cell generations is 2.86 (range $2 \cdot 26$ to $3 \cdot 49$ ), the largest increases occurring in subcultures 7, 8, and 9.

Comparing the primary transfer ( $24 \mathrm{hrs}$ ) with the subculture 9 of both culture systems, there were total percentage increases in the number of cell generations of 22 and 25, with associated total percentage decreases in the number of motile cells of 25 and 27 respectively.

Table III shows the growth of virulent treponemes occurring in both tissue culture systems regardless of the declining number of motile organisms.

In the TCM-1-BHK-21 culture system, the counted number of cultured treponemes adjusted to $10^{5}$ in $0.1 \mathrm{ml}$. volumes produced ID lesions providing estimated numbers of virulent organisms of $10^{7}$,
$6 \times 10^{5}, 10^{5} 10^{6}$, and $10^{6}$ respectively for subcultures $1,4,5,7$, and 8 . The counted number of cultured treponemes adjusted to $10^{3}$ in $0.1 \mathrm{ml}$. volumes produced ID lesions providing estimated numbers of virulent organisms of $6 \times 10^{4}$ and $6 \times 10^{4}$ respectively for subcultures 7 and 8 .

In the TCM-2-BHK-21 culture system, the counted number of cultured treponemes adjusted to $10^{5}$ in $0.1 \mathrm{ml}$. volumes produced ID lesions providing estimated numbers of virulent organisms of $10^{6}$ and $6 \times 10^{5}$ respectively for subcultures 1 and 5 . The counted number of cultured organisms adjusted to $10^{3}$ in a $0.1 \mathrm{ml}$. volume produced ID lesions providing an estimated number of virulent treponemes of $10^{4}$ for subculture 1 .

In Table IV the estimated numbers of virulent treponemes are compared with the estimated numbers of organisms transferred from the original (initial) inoculum. The number of the original organisms inoculated decreased; this is estimated by the dilution factor encountered when the number of cultured treponemes was adjusted for each subculture. Accordingly, as the number of cell generations increases with each subculture, so does the dilution factor, thereby directly effecting a decrease in the original number of treponemes initially inoculated at the beginning of the subculturing experiments.

\section{Discussion}

Successful growth and subculture of virulent $T$. pallidum has been accomplished in serum-free tissue culture systems. The success is principally based upon three important factors: initial numbers of cultured tissue cells, subculturing frequency, and duration of infection in the animal from which the virulent organisms are initially obtained.

The tissue cell monolayer should be no more than a +2 confluency at the time of treponemal inoculation. It has been our experience that the majority of the virulent treponemes inoculated on confluent

TABLE II Growth of T. pallidum cells subcultured in two BHK-21 tissue culture systems *

\begin{tabular}{|c|c|c|c|c|c|c|c|c|c|c|c|}
\hline \multirow{2}{*}{\multicolumn{2}{|c|}{ Subculture }} & \multicolumn{10}{|c|}{ Concurrent experiments } \\
\hline & & \multicolumn{5}{|c|}{$A(T C M-1)$} & \multicolumn{5}{|c|}{$B(T C M-2)$} \\
\hline \multirow{2}{*}{ No. } & \multirow{2}{*}{$\begin{array}{l}\text { Hrs after } \\
\text { harvest }\end{array}$} & \multicolumn{4}{|c|}{ Cell count $\times 10^{5} / \mathrm{ml}$. } & \multirow{2}{*}{$\begin{array}{l}\text { No. of cell } \\
\text { generations }\end{array}$} & \multicolumn{4}{|c|}{ Cell count $\times 10^{5} / \mathrm{ml}$. } & \multirow{2}{*}{$\begin{array}{l}\text { No. of cell } \\
\text { generations }\end{array}$} \\
\hline & & Initial & $(\% M o) \dagger$ & Final & $(\% M o)$ & & Initial & $(\% M o)$ & Final & $(\% M o)$ & \\
\hline $\begin{array}{l}0 \\
1 \\
2 \\
3 \\
4 \\
5 \\
6 \\
7 \\
8 \\
9\end{array}$ & $\begin{array}{r}24 \\
48 \\
72 \\
96 \\
120 \\
144 \\
168 \\
192 \\
216 \\
240\end{array}$ & $\begin{array}{l}1 \cdot 87 \\
2 \cdot 03 \\
2 \cdot 03 \\
1 \cdot 99 \\
2 \cdot 03 \\
2 \cdot 15 \\
2 \cdot 11 \\
2 \cdot 35 \\
1 \cdot 87 \\
2 \cdot 27\end{array}$ & $\begin{array}{l}(100) \\
(100) \\
(100) \\
(93) \\
(95) \\
(83) \\
(84) \\
(89) \\
(82) \\
(78)\end{array}$ & $\begin{array}{l}11 \cdot 1 \\
13 \cdot 2 \\
13 \cdot 7 \\
15 \cdot 4 \\
18 \cdot 1 \\
21 \cdot 0 \\
15 \cdot 2 \\
14 \cdot 8 \\
20 \cdot 7 \\
22 \cdot 4\end{array}$ & $\begin{array}{l}(100) \\
(100) \\
(93) \\
(95) \\
(83) \\
(84) \\
(89) \\
(82) \\
(78) \\
(75)\end{array}$ & $\begin{array}{l}2 \cdot 57 \\
2 \cdot 70 \\
2 \cdot 75 \\
2 \cdot 95 \\
3 \cdot 16 \\
3 \cdot 29 \\
2 \cdot 85 \\
2 \cdot 66 \\
3 \cdot 47 \\
3 \cdot 30\end{array}$ & $\begin{array}{l}1 \cdot 87 \\
2 \cdot 03 \\
2 \cdot 03 \\
2 \cdot 07 \\
2 \cdot 11 \\
2 \cdot 31 \\
2 \cdot 27 \\
2 \cdot 23 \\
1 \cdot 91 \\
2 \cdot 15\end{array}$ & $\begin{array}{l}(100) \\
(100) \\
(100) \\
(90) \\
(96) \\
(94) \\
(81) \\
(87) \\
(84) \\
(78)\end{array}$ & $\begin{array}{r}10 \cdot 0 \\
9 \cdot 7 \\
12 \cdot 6 \\
13 \cdot 1 \\
15 \cdot 1 \\
17 \cdot 8 \\
15 \cdot 9 \\
22 \cdot 0 \\
21 \cdot 4 \\
20 \cdot 0\end{array}$ & $\begin{array}{l}(100) \\
(100) \\
(90) \\
(96) \\
(94) \\
(81) \\
(87) \\
(84) \\
(78) \\
(73)\end{array}$ & $\begin{array}{l}2 \cdot 42 \\
2 \cdot 26 \\
2 \cdot 63 \\
2 \cdot 66 \\
2 \cdot 84 \\
2 \cdot 95 \\
2 \cdot 81 \\
3 \cdot 30 \\
3 \cdot 49 \\
3 \cdot 23\end{array}$ \\
\hline
\end{tabular}

*Incubation at $33^{\circ} \mathrm{C}$. in 7 per cent. carbon dioxide in air

$\dagger(\%$ Mo $)=$ Percentage of cells motile 
$(+4)$ monolayers or into large numbers of cultured cells in suspension rapidly adhere to the cells throughout the cultivation period studied, making treponemal cell counts difficult, variable, and subject to criticism. This experience has recently been reported by other scientists (Fitzgerald and others, 1975). Using few cultured cells ( +2 monolayer confluency) provides treponemal cell counts that are consistent and reproducible.

Adherence to tissue cells may be due to the extracellular slime layer on the surface of pathogenic $T$. pallidum cells as demonstrated by Zeigler, Jones, Jones, and Kubica (1976). In this study an extracellular slime layer was not observed on two nonpathogenic treponemes (Treponema refringens biotype
Nichols and Treponema phagedenis biotype reiterii). Adherence of pathogenic $T$. pallidum cells to testicular cells in vivo was directly shown to be a function of the extracellular slime layer. Also, it has been reported that biotype reiterii cells do not adhere to tissue cells (Fitzgerald and others, 1975).

Frequent subculturing (every $24 \mathrm{hrs}$ ) of infected tissue culture cells was found necessary for the continued cultivation of significant numbers of virulent treponemes. In similar experiments, in which subculturing was not done every $24 \mathrm{hrs}$, continuous cultivation of significant numbers of virulent treponemes was not achieved. The subculturing frequency of $24 \mathrm{hrs}$ is tiresome and, without the use of antibiotics, the cultures are subject to contamination.

TABLE III Virulence of T. pallidum cells subcultured in two BHK-21 tissue culture systems

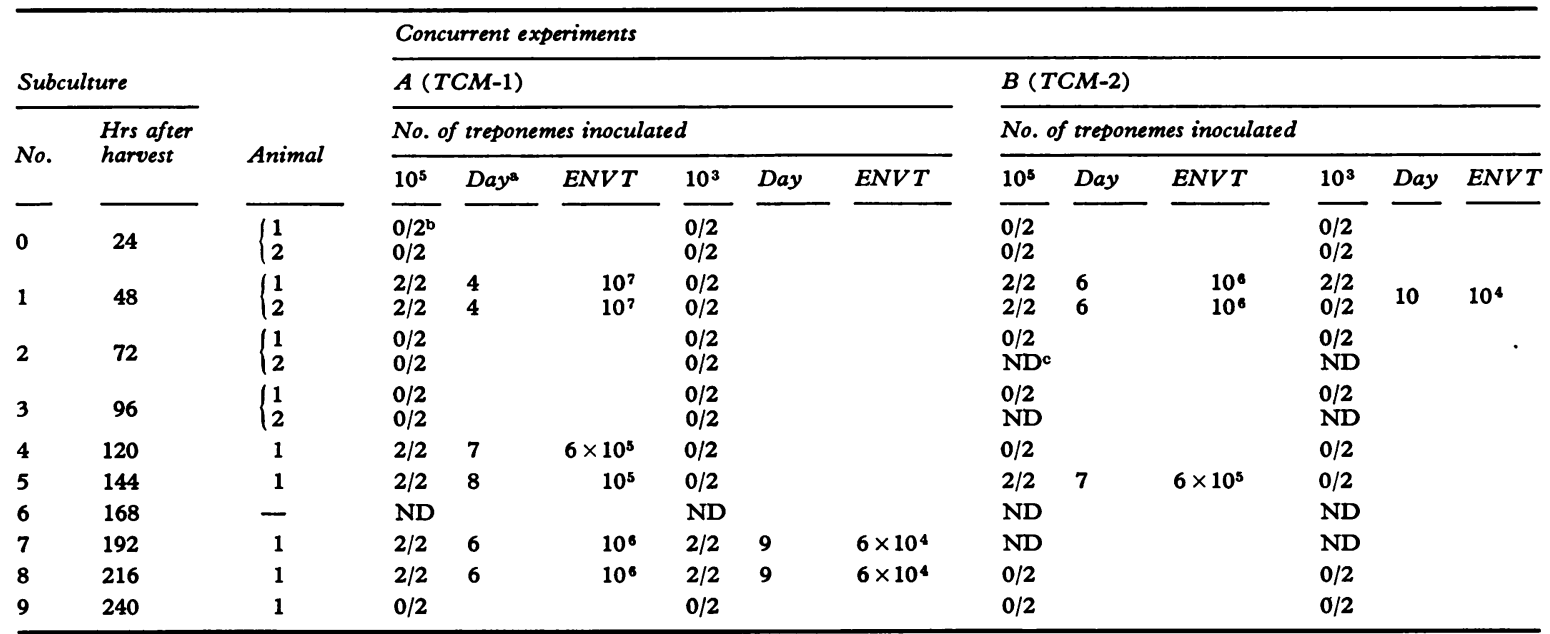

-Day of lesion appearance

DNumber of sites having developed lesions/number of sites injected intradermally

ENVT = estimated number of virulent treponemes in $0.1 \mathrm{ml}$. inoculum, based on time of lesion appearance

cND = not done

TABLE IV Comparison of estimated number of treponemes transferred from original harvest $(E O N)$ and estimated number of virulent cells in $0.1 \mathrm{ml}$ inoculum (ENVI)

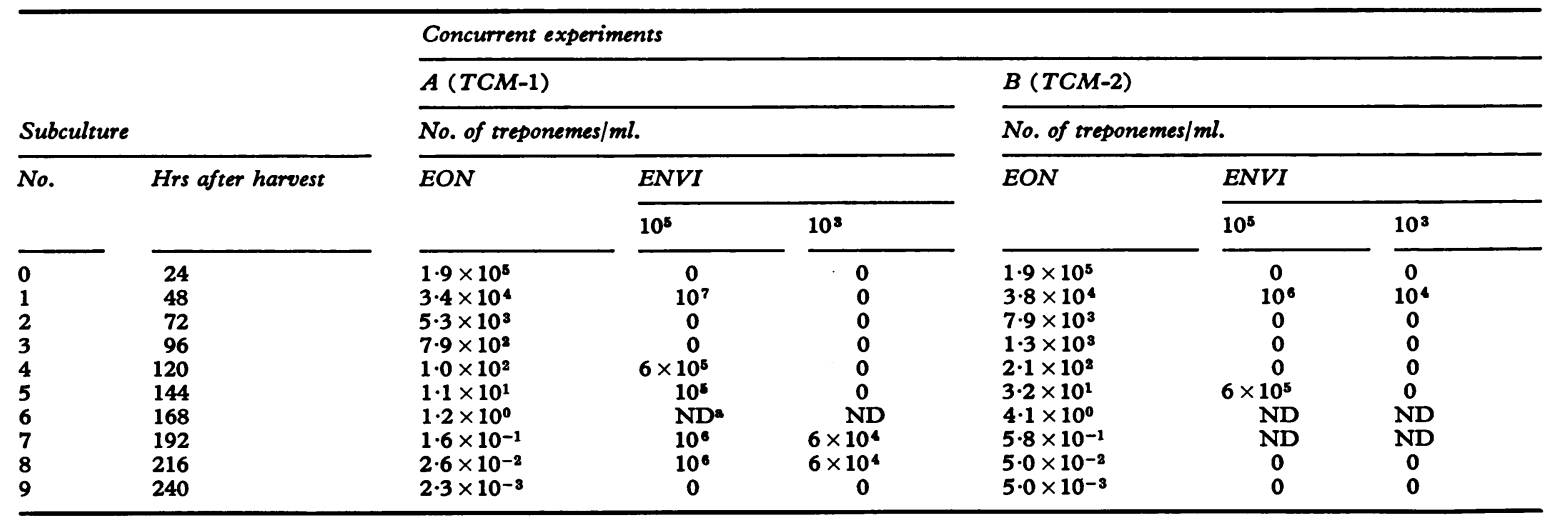

ND $=$ not done 
The duration of treponemal infection in the testes from which the organisms are taken appears to be an important consideration for continued cultivation. In similar experiments, organisms from 12 to 18-dayold rabbit testicular infections were inoculated into BHK-21, HeLa, MK-2, and rabbit testicular (adapted primary) cultured tissue cells and caused tissue cell lysis within 24 to $72 \mathrm{hrs}$. Cell-free supernatant fluids derived from these lysed cultures caused cell lysis when added to fresh uninoculated cultured cells. The treponemes used in the present study were derived from 43-day-old testicular infections in rabbits. Apparently, a cytotoxic factor(s) is present or exists at higher levels in the cell harvests from more recent infections.

In comparing the two nutritional systems tested, little difference in the performance of treponemal growth was observed. The TCM-1-BHK-21 culture system showed virulent treponemes more consistently than TCM-2-BHK-21, as judged by ID injections. However, this might not have been the case if an equal number of animals had been injected with treponemes grown in TCM-2-BHK-21 culture system.

Analysing Table IV, it is significant that, in every case in which lesions developed, the estimated number of virulent treponemes is higher than or equal to the counted cultivated treponemes. This may be explained by the injection of additional virulent treponemes occurring intracellularly, since only the cultivated extracellular treponemes were counted. The intracellular presence of pathogenic treponemes has been documented in lesions, and in tissue cells cultured in vitro and subsequently infected with virulent treponemes (Sykes and Miller, 1971; Sykes, Miller, and Kalan, 1974; Fitzgerald and others, 1975; Sykes and Kalan, 1975).

That the estimated number of virulent treponemes represents non-cultivated virulent organisms from the original number is disputed by the dilution of this inoculum through the subculturing procedures.

The cases in which no virulence (lesion development) was observed cannot be explained. This might not have occurred if more animals had been inoculated. Also, no consistency was observed between virulence and increase in cell generation numbers. The production of treponemes or the presence of the extracellular slime layer (a possible virulence factor) may have been variously affected by the nutritional systems and/or mechanical procedures of subculturing, which could contribute to the inconsistent findings in virulence. Since the amount of slime layer was observed to vary from cell to cell (Zeigler and others, 1976), it is possible that populations of smooth and rough forms exist. This is a subject of intensive study at this Institute.

Ever since the discovery of T. pallidum in 1905 research concerning the cultivation of the organism in vitro has centred in anaerobic media and incubation conditions. Early workers noted that the organisms quickly died, upon exposure to air, but Perry (1948) maintained the organisms in a tissue culture system using oxygen and $\mathrm{CO}_{2}$ and the organisms remained virulent for at least 10 days; however, definitive studies were not conducted. Also, Cox and Barber (1974) reported that $T$. pallidum utilized oxygen, but they did not conduct any growth and virulence studies.

A traditional theory of microbiology holds that anaerobic micro-organisms are poisoned by mechanisms involving conversion by the organisms of $\mathrm{O}_{2}$ to $\mathrm{H}_{2} \mathrm{O}_{2}$ which, in turn, causes self-destruction unless the organism or growth milieu possesses catalase. Recent investigations have indicated that the oneelectron reduction product of oxygen, the superoxide ion, may also be toxic to micro-organisms (Lavelle, Michelson, and Dimitrijenic, 1973). The superoxide ion is destroyed by the enzyme superoxide dismutase. However, this reaction also occurs spontaneously in the absence of the enzyme. Gregory and Fridovich (1974) postulated that the truly damaging species is the hydroxyl radical produced by the reaction of hydrogen peroxide with superoxide.

Therefore, it has been suggested that perhaps $T$. pallidum is truly an aerobic organism producing superoxide abundantly which during active metabolism results in the production of high levels of hydroxyl radicals subsequently poisoning the organisms in cell-free culture systems in vitro. Gregory and Fridovich (1974) also demonstrated that the hydroxyl radical can be successfully scavenged by mannitol. Therefore, from the foregoing, mannitol and catalase were tested in TCM-1-BHK-21 system and hydroxyl radical production periodically monitored during the subcultivation in both systems using a dye photometric test (Hatada, Kraljic, El Samahy, and Trumbore, 1974). Treponemes occurring in supernatant fluids showed hydroxyl radical production only in the TCM-2-BHK-21 culture systems to which catalase and mannitol were not added. The relationship, if any, between the production of hydroxyl radicals, cell growth, production of extracellular surface material, and cell virulence is currently unclear. It is of interest that free hydroxyl radicals depolymerize hyaluronic acid (McCord, 1974) and that it has been suggested that the extracellular surface material may contain a similar carbohydrate (Zeigler and others, 1976).

This study was supported by PHS grants CC-00686 and CC-00687 from the Center for Disease Control, Atlanta, and grant 74346 from The John A. Hartford Foundation, New York City. 


\section{References}

Chandler, F. W., Jr., and Cannefax, G. R. (1969) Brit. f. vener. Dis., 45, 1

Cox, C. D., and BARBER, M. K. (1974) Infect. and Immun., 10,123

EAGLE, H. (1959) Science, 130, 432

EARLE, W. H. (1943) Nat. Canc. Inst., 4, 167

FitzGerald, T. J., Miller, J. N., and Sykes, J. A. (1975) Infect. and Immun., 11, 1133

GrEgory, E. M., and FrIDOvich, I. (1974) f. Bact., 117, 166

Hatada, M., Kraljic, I., El Samahy, A., and Trumbore, C. N. (1974) $\mathcal{F}$. phys. Chem., 78, 888

Lavelle, F., Michelson, A. M., and Dimitrijenic (1973) Biochem. Biophys. Res. Comm., 55, 350

Levaditi, F., and Danulesco, V. (1912) C. R. Soc. Biol. (Paris), 73, 256

MACPHERSON, I. A., and StOKER, M. (1962) Virology, 16, 147

McCoRd, J. M. (1974) Science, 185, 529

Noguchi, H. (1911) f. Amer. med. Ass., 57, 102
(1912) f. exp. Med., 15, 90

Perry, W. L. M. (1948) f. Path. Bact., 60, 339

SCHERESCHEWSKY, J. (1909a) Dtsch. med. Wschr., 35, 835

- (1909b) Ibid., 35, 1260

(1909c) Ibid., 35, 1652

(1912) Ibid., 38, 1315

(1955) Arch. Derm. Syph. (Berl.), 200, 456

Small, J. D., and Newman, B. (1972) Lab. Animal Sci., 22, 77

SyKeS, J. A., and KALAN, J. (1975) Amer. F. Obstet. Gynec., 122, 361

— and MilleR, J. N. (1971) Infect. and Immun., 4, 307

$$
\text { 50, } 40
$$

Turner, T. B., and Hollander, D. H. (1957) 'Biology of the Treponematoses', p. 278. World Health Organization, Geneva

Willcox, R. R., and Guthe, T. (1966) W. H. O. Bull., 35, Suppl. 1

ZeigleR, J. A., Jones, R. H., Jones, A. M., and KubicA, K. M. (1976) Brit. F. vener. Dis., 52, 1 
Trimethoprim-sulfamethoxazole in the Treatment of Chronic Prostatitis DOW, D. (1975)

Canad. med. Ass. F., 112, 26

Semen Cultures in Diagnosis of Bacterial Prostatitis MOBLEY, D. F. (1975) f. Urol. (Baltimore), 114, 83

\section{Streptococcal Cellulitis of} Scrotum and Penis with Secondary Skin Gangrene HAURY, B., RODEHEAVER, G., STEVENSON, T., BACCHETTA, C., EDGERTON, M. T., and EDLICH, R. F. (1975) Surg. Gynec. Obstet., 141, 35
Circinate Erosive Balanitis and

HLA-27 LASSUS, A., TIILIRAINEN, A., STUBB, S., REUNALA, T., and JOHANSSON, E. (1975) Acta derm.venereol. (Kbh.), 55, 199

Hepatitis-B Antigen in Venereal Diseases KAČAKI, J., SCHUURS, A. H. W. M., WOLTERS, G., and LALOSEvič, J. (1975) Lancet, 2, 363 (Letter)

Lymphocyte Stimulation in Hepatitis B Infections TONG, M. J., WALLACE, A. M., PETERS, R. L., and REYNOLDS, T. B. (1975) New Engl. F. Med., 293, 318
Proceedings of a Symposium on

Viral Hepatitis (23 papers) (1975)

Med. Sci., 270, 213-409

Venereal Disease: Interviewing and Teaching by Computer VAN CURA, L. J., JENSEN, N. M., GREIST, J. H., LEWIS, W. R. and FREY, S. R. (1975) Amer.

f. publ. Hlth, 65, 1159

\section{Correction}

In the paper by R. H. Jones, M. A. Finn, J. J. Thomas, and E. C. Folger, which appeared in the February issue of the journal (British fournal of Venereal Diseases (1976), $52,18)$ the second paragraph, right hand column, p. 19, should read as follows:

The BSA-sodium stearate complex was made by dissolving $5 \mathrm{mg}$ stearic acid in $25 \mathrm{ml} 0.1 \mathrm{~N} \mathrm{NaOH}$ at $75^{\circ} \mathrm{C}$. This solution was cooled to below $50^{\circ} \mathrm{C}$ (during which small additions of $0.1 \mathrm{~N} \mathrm{HCl}$ or $0.1 \mathrm{~N} \mathrm{NaOH}$ may be needed to maintain solubility) and then added to $20 \mathrm{ml}$ of a 10 per cent. BSA solution and $20 \mathrm{ml}$ GKNP; the total volume was added to the final medium. This BSA-sodium stearate complex must be prepared and used the same day. 